\title{
THE
}

\section{Using Interactive Nutrition Modules to Increase Critical Thinking Skills in College Courses}

Jade McNamara

Sara Sweetman

University of Rhode Island, sara_sweetman@uri.edu

Priscilla Connors

Ingrid E. Lofgren

University of Rhode Island, ingrid_lofgren@uri.edu

Geoffrey Greene

University of Rhode.Island, ggreene@uri.edu Follow this and additional'works at: $h t t p s: / / d i g i t a l c o m m o n s . u r i . e d u / n f s \_f a c p u b s$

The University of Rhode Island Faculty have made this article openly available. Please let us know how Open Access to this research benefits you.

This is a pre-publication author manuscript of the final, published article.

Terms of Use

This article is made available under the terms and conditions applicable towards Open Access Policy Articles, as set forth in our Terms of Use.

\section{Citation/Publisher Attribution}

McNamara, J., Sweetman, S., Connors, P., Lofgren, I., \& Greene, G. (2019). Using Interactive Nutrition Modules to Increase Critical Thinking Skills in College Courses. Journal of Nutrition Education and Behavior, 52(4), 343-350. doi: 10.1016/j.jneb.2019.06.007

Available at: https://doi.org/10.1016/j.jneb.2019.06.007

This Article is brought to you for free and open access by the Nutrition and Food Sciences at DigitalCommons@URI. It has been accepted for inclusion in Nutrition and Food Sciences Faculty Publications by an authorized administrator of DigitalCommons@URI. For more information, please contact digitalcommonsgroup@uri.edu. 


\section{Journal of Nutrition Education and Behavior \\ USING INTERACTIVE NUTRITION MODULES TO INCREASE CRITICAL THINKING SKILLS IN COLLEGE COURSES \\ --Manuscript Draft--}

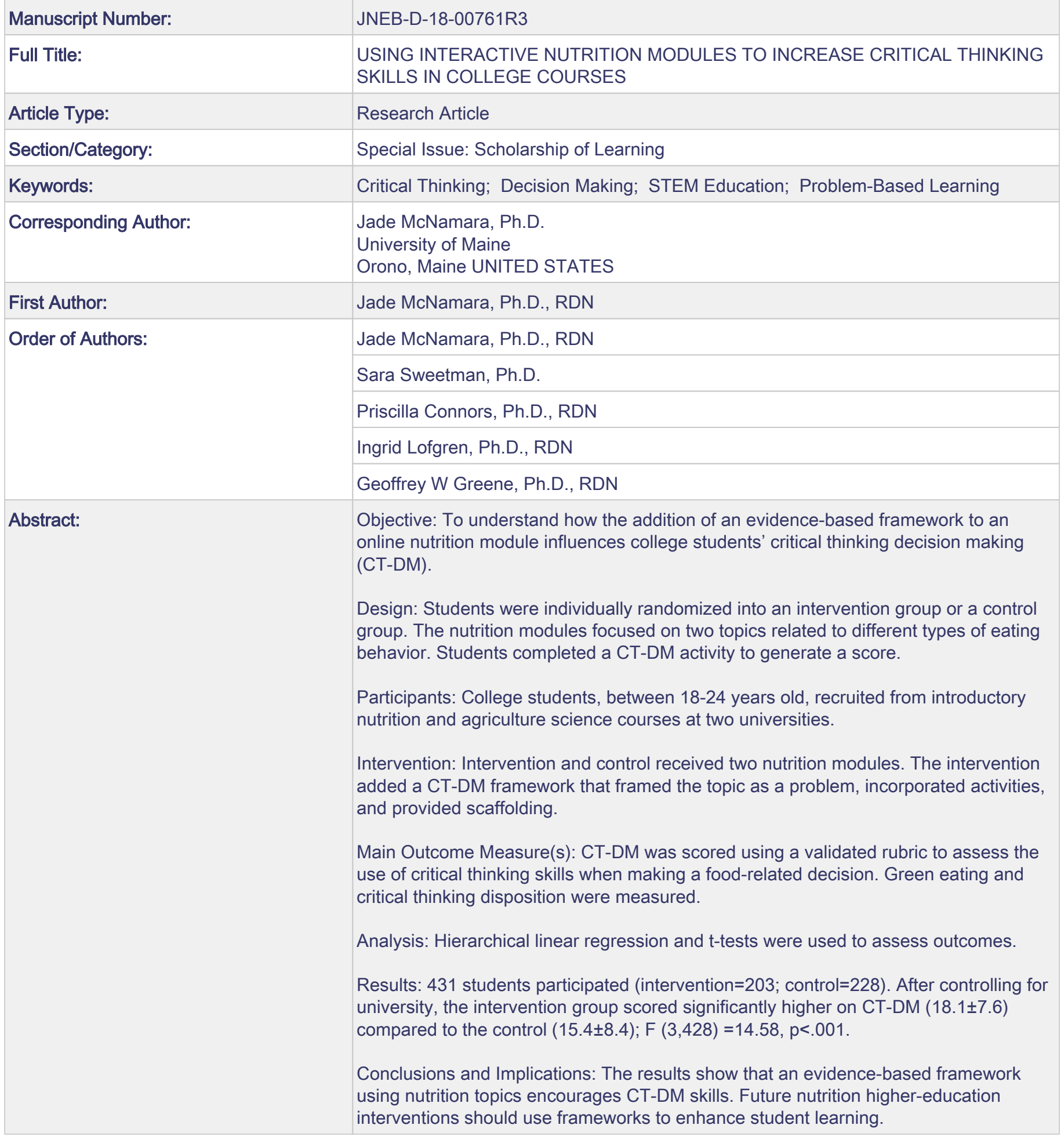




\section{Cover letter:}

This manuscript is being submitted as a Research Article. The manuscript was written specifically for the Scholarship of Learning special issue. This research focuses on how evidence-based instructional practices can be used to encourage critical decision making skills in introductory nutrition and agriculture courses. The manuscript has not been and will not be submitted elsewhere for publication. The evidence-based instructional practices that were operationalized and used in this research were described and evaluated in a separate manuscript that is currently under review, however, no overlapping outcomes between the manuscripts were used. All authors have reviewed and approved the complete manuscript including tables and the figure. The complete page count is 18 pages and 5,212 words.

Potential reviewers:

Sarah Martin Gould, PhD, RDN

Associate Professor

University of Northern Colorado, School of Human Sciences, Nutrition and Dietetics Program, Greeley, CO

Email: susan.gould@unco.edu

Phone: 970-351-1705

Dustin Perry, PhD

Assistant Professor

Montana State University

Division of Agricultural Education College of Agriculture Montana State University (MSU), Bozeman, MT

E-mail: Dustin.Perry@Montana.edu

Phone: 406-994-5773 


\section{TITLE PAGE}

\section{USING INTERACTIVE NUTRITION MODULES TO INCREASE CRITICAL THINKING SKILLS IN COLLEGE COURSES}

\section{Research Article}

Jade McNamara, PhD. ${ }^{1}$, Sara Sweetman, Ph.D. ${ }^{2}$, Priscilla Connors, Ph.D., RDN ${ }^{3}$, Ingrid Lofgren, Ph.D., RDN ${ }^{4}$, Geoffrey Greene, Ph.D., $\mathrm{RDN}^{4}$

1. School of Food and Agriculture, University of Maine, Orono, ME

2. School of Education, University of Rhode Island, Kingston, RI

3. College of Merchandizing, Hospitality and Tourism, University of Northern Texas, Denton, TX

4. Department of Nutrition and Food Science, University of Rhode Island, Kingston, RI

Corresponding Author:

Jade McNamara

7 Portage Road

University of Maine

Orono, ME 04469

Phone Number: 207-581-4895

E-mail: jade.mcnamara@maine.edu

This research was completed while Jade McNamara was at the University of Rhode Island

41 Lower College Rd

University of Rhode Island

Kingston, RI 02881

\section{Acknowledgments}

This research was conducted as part of Jade McNamara's dissertation research. The development of the online applications was produced by the University of Rhode Island's Media and Technology Department. Thank you to the Undergraduate Research Assistants who scored the critical thinking decision making responses. 


\begin{abstract}
Objective: To understand how the addition of an evidence-based framework to an online nutrition module influences college students' critical thinking decision making (CT-DM).
\end{abstract}

Design: Students were individually randomized into an intervention group or a control group. The nutrition modules focused on two topics related to different types of eating behavior. Students completed a CT-DM activity to generate a score.

Participants: College students, between 18-24 years old, recruited from introductory nutrition and agriculture science courses at two universities.

Intervention: Intervention and control received two nutrition modules. The intervention added a CT-DM framework that framed the topic as a problem, incorporated activities, and provided scaffolding.

Main Outcome Measure(s): CT-DM was scored using a validated rubric to assess the use of critical thinking skills when making a food-related decision. Green eating and critical thinking disposition were measured.

Analysis: Hierarchical linear regression and t-tests were used to assess outcomes.

Results: 431 students participated (intervention=203; control=228). After controlling for university, the intervention group scored significantly higher on CT-DM (18.1 \pm 7.6$)$ compared to the control $(15.4 \pm 8.4) ; \mathrm{F}(3,428)=14.58, \mathrm{p}<.001$.

Conclusions and Implications: The results show that an evidence-based framework using nutrition topics encourages CT-DM skills. Future nutrition higher-education interventions should use frameworks to enhance student learning.

(Word Count: 200)

Key Words: Critical Thinking, Decision Making, STEM Education, Problem-Based Learning 


\section{USING INTERACTIVE NUTRITION MODULES TO INCREASE CRITICAL THINKING SKILLS IN COLLEGE COURSES}

\section{INTRODUCTION}

Twenty first century skills that include critical thinking, have been identified by employers of college graduates as more important than academic success in making hiring decisions. ${ }^{1-3}$ This is, in part, related to the increasing pace of scientific discovery and advances in technology that requires critical thinking skills. There is evidence that individuals with high level critical thinking skills make better decisions, such as taking less unnecessary risks, than those with less developed critical thinking skills. ${ }^{1,4}$ However, teaching critical thinking skills in introductory college courses is challenging, particularly in science, technology, engineering and math (STEM) disciplines such as nutrition and animal sciences where there is a high focus on memorizing critical information. ${ }^{5,6}$ There also have been few research studies focusing on the science of teaching and learning addressing critical thinking within STEM courses.

Critical thinking skills include the ability to apply standards, seek out information, problem solve, transform knowledge, predict consequences of decisions, be creative, practice logical reasoning, and evaluate evidence when faced with a problem or question. ${ }^{7-9}$ Because critical thinking is such a broad construct and includes so many skills, it is difficult to measure for educational outcomes. ${ }^{10}$ Narrowing the construct of critical thinking to critical thinking decision making (CT-DM), defined by having skills in problem solving, logical reasoning, and evaluating evidence when making decisions ${ }^{9}$, allows for realistic measurement methods and facilitates curriculum development. 
A learner-centered curriculum fosters CT-DM by allowing students to connect thoughts

27 and ideas through reflection of what they already know, investigation of new knowledge, and

28 explicit skill development. ${ }^{11,12}$ Learner-centered curricula can be operationalized through the

29 theory of social constructivism using problem-based learning (PBL) activities. ${ }^{13,14}$ Social

30 constructivism theory postulates that students learn by connecting concepts to previous

31 knowledge and experiences ${ }^{15,16}$, while PBL provides students with opportunities to assess

32 complex problems using a variety of resources, and develop their own strategies for addressing

33 these problems. ${ }^{17,18}$ However, incorporating PBL into introductory STEM classes is difficult due

34 to discipline and accreditation demands for course content. One solution to overcome these time

35 constraints has been to utilize out-of-class, online PBL activities to enhance skill development

36 and motivate students to engage in learning activities. Additionally, students have expressed

37 frustration with PBL activities, particularly in introductory courses, because of a lack of

38 framework to successfully complete the tasks, ${ }^{19}$ which underscores the importance of

39 intentionally designing activities and using topics that motivate students to engage in learning.

In addition to pedagogical strategies, personal factors such as attitude towards critical

41 thinking or interest in the PBL topic may affect student engagement with the curriculum. ${ }^{20,21}$

42 Some students are naturally more open to using critical thinking skills, which has been assessed

43 in previous research by the critical thinking disposition scale (CTD $)^{22}$, which may influence the

44 outcome of a CT-DM intervention. Also, researchers have shown that personal interest in a topic

45 motivates students to participate, express their point of view and engage in a learning activity. ${ }^{23}$

46 For example, nutrition and food choice topics are ideal for motivating students to engage in

47 learning because the majority can connect with those scenarios as they are making eating and

48 food choice decisions daily. One way of assessing personal interest in a topic is by measuring 
49 self-reported behaviors pertaining to the topic. Both variables, CTD and personal interest in a

50 topic, need to be measured to evaluate the role they play in explaining CT-DM.

51 Thus, the primary objective was to determine if the addition of a contextual framework,

52 defined in this study as the critical thinking decision making framework (CTDM-F), to a two-

53 module, online PBL curriculum influences college students' CT-DM skills. The second objective

54 was to explore the relationship between the mediating factors of CTD and personal interest in a

55 topic on CT-DM skills. The primary hypothesis was that undergraduate students exposed to the

56 CTDM-F would have a significantly higher CT-DM score when compared to the students in the

57 control group and that CTD and interest in the topic would be mediators of CT-DM score.

\section{Research Design}

This study was a randomized controlled trial, where students from two geographically

64 diverse universities (University of Rhode Island and University of North Texas) were recruited

65 from introductory level nutrition and animal science courses, and individually randomized into to

66 a CTDM-F group or a control group. The study was approved at both universities by their

67 respective Institutional Review Boards. Students were provided with a link to access the online

68 consent to participate in the research study and sign-up for the modules. Students were then

69 randomized into either the CTDM-F group or control group by the computer. Students were then

70 directed to an online pretest, assessing key mediating variables such as inclination to use critical

71 thinking (measured by CTD), prior interest in the topic of sustainable eating (measured by green

72 eating behavior (GE)) and demographic data. They were then immediately directed to the first

73 module: pros and cons of animal protein vs. non-animal protein food choices. One week later, 
74 they were notified that the second module was available: pros and cons of organic food vs. non-

75 organic food choices. The post-test immediately followed module 2, which was similar to the

76 pretest.

77 The topics for the modules, animal vs. plant-based sources of protein and organic vs.

78 non-organic food, were chosen because both topics can be argued from multiple perspectives and

79 relate to authentic scenarios that college students may face when making food purchasing or

80 eating decisions. As higher education institutions move towards providing greater education on

81 sustainable practices and sustainably produced food choices ${ }^{24}$, college students will be faced

82 with these decision making scenarios. Previous research also supports that college students are

83 interested in topics related to environmentally conscious eating and find these topics motivating

84 for learning. ${ }^{25}$

\section{CT-DM Module and Control Module}

Both modules were easily accessible to students from various platforms via internet

87 connections and took about 15 minutes to complete. Module 1 began with an interactive "quiz"

88 to determine what type of learner the student was, a video discussing the importance of critical

89 thinking, and two videos addressing both sides of the specific topic area (animal protein vs. non-

90 animal protein foods). After watching the topic video, the student was asked to make a decision

91 about which side they agreed with and then were prompted to write a brief response explaining

92 why they made that decision. Module 2 had the same format as module 1 and then was followed

93 by the post-test.

94 Critical Thinking Decision-Making Framework

95 The CTDM-F was designed using the social constructivism model with the aim to bring

96 about a conceptual change in student thinking by having the student construct their own 
97 conclusions when presented with information. ${ }^{15,16}$ Scaffolding, or structuring the learning

98 process to help the learner more towards independence, was also a key component in the CTDM-

99 F. ${ }^{15,16}$ The three specific strategies to operationalize an online delivery of social constructivism

100 with an emphasis on scaffolding, were as follows: 1) topic was introduced as an authentic

101 problem $\left.^{26}, 2\right)$ an input scaffold in the form of a t-chart was provided to help organize information

102 from the two sources with alternative views ${ }^{27}$, and 3) an output scaffold was provided to help

103 frame the argument separate from decision making ${ }^{28}$, in the form of a "mind-map". The "mind-

104 map" was an activity where students structured their response with their decision and reasoning

105 using a drag-and-drop activity. For module 1, the CTDM-F provided more scaffolding for the

106 decision-making activity by using a closed exercise format with fill-in-the-blanks structured

107 responses. For module 2, the scaffolding in the decision-making activity was removed by

108 providing only a blank text box for recording the decision-making response.

109 Control Module. The control group was exposed to the same videos but did not have the topic

110 introduced as a problem, did not receive the input scaffold and did not have an output scaffold.

111 They were provided with a blank decision-making text box in both modules. The differences in

112 the layout of module 1 and module 2 between groups is described in Table 1.

113 [TABLE 1]

114 Measurements

115 Primary Outcome: Critical Thinking Decision-Making Score. To calculate the CT-DM score,

116 a previously developed and tested rubric $^{29}$ was used to score the decision-making activity at the

117 end of module 2, when both groups received the text box. Scores ranged from 0-30, evaluating

118 the extent of CT-DM, with 0 representing a non-response/failed to provide a text response

119 addressing the task, and 30 indicating a text response that addressed the three following 
120 constructs: 1$)$ ability to make a decision (0/10 points), 2$)$ evidence to support the decision (0-15

121 points), and 3$)$ ability to see the other side's point of view ( $0 / 5$ points). The responses were

122 scored using a computer-assisted scoring system that guided trained researchers through the

123 response criteria generating a total score. The passing rate for training was set at an interrater

124 reliability (IRR) score of $\geq .80$, which has been used in previous research as an acceptable

125 agreement score. ${ }^{30}$ All responses were duplicate scored by research assistants $(\mathrm{n}=4)$ who

126 participated in training and were evaluated for reliability based on matching rate. Scores that did

127 not match (18\%) were then scored by a senior researcher to determine a final score.

128 Critical Thinking Disposition. Disposition to use critical thinking operationalized as CTD was

129 measured using a 5-item subscale from the Motivated Strategies for Learning Questionnaire

130 (MSLQ). ${ }^{22}$ The subscale was designed and validated to measure college students' thinking

131 strategies to apply knowledge and critically evaluate situations and found to have good internal

132 reliability with a Cronbach's alpha $(\alpha)$ value of $.72 .{ }^{31}$ The composite score is an indicator of

133 students' inclination to use CT during a decision-making process. ${ }^{22}$ The five items were

134 measured using a 5-point Likert scale, ranging from (1) strongly disagree (5) strongly agree.

135 Green Eating Behavior. Prior interest in the topic, operationalized as GE behavior, was

136 measured using a validated 7-item survey $(\alpha=.81)$, which assessed the frequency of choosing

137 sustainably produced food. ${ }^{24}$ The items included behaviors related to purchasing foods locally

138 grown, shopping at farmer's markets, buying organic, and purchasing free-range animal proteins.

139 Items were measured on a 5-point Likert scale ranging from (1) barely ever to never to (5)

140 almost always, a higher score indicating a greater frequency of choosing sustainably produced

141 foods.

\section{Data Analysis}


144 were analyzed for normal distribution using values of -2 to +2 for skewness and kurtosis. ${ }^{32}$

145 Demographic variables were analyzed using means ( \pm standard deviation) and frequency (\%).

146 Independent t-tests were used to analyze baseline differences between the CTDM-F and the

147 control groups, and between universities. Analysis of covariance (ANCOVA) was conducted at

148 baseline to control for significant differences between groups. A Pearson's Chi-square test of

149 independence analysis was used to analyze categorical variables. To assess differences in CT-

150 DM score between groups, a two-stage hierarchical multiple regression was performed with CT-

151 DM score as the dependent variable. University was entered at stage one of the regression to

152 control for differences at baseline. Group (control vs CTDM-F) was entered at stage two to

153 assess differences between groups on CT-DM score after controlling for university. ANCOVA

154 was also used to assess differences in scores and components of the CDM score between groups.

155 To evaluate change in CTD score and GE behavior from baseline to post-intervention, repeated

156 measures ANCOVA was conducted. For all the analyses significance level was set at $p<0.05$. An

157 exploratory structural equation model (SEM) using path analysis was also performed to explore

158 the amount of variation that was accounted for in CT-DM score by group, CTD, and GE

159 behavior. For the SEM outcomes, ideal macro-level fit indices parameters include: $\chi^{2} \mathrm{p}>.05$,

$160 \chi^{2} /$ df ratio $<4, \mathrm{CFI}>.90$, RMSEA $<.08$, and for $\chi^{2}$ difference, a larger value equates to better

161 fit. $^{32}$ 
A total of 440 students randomly assigned to either the control $(n=230)$ or the CTDM-F

167 group $(\mathrm{n}=210)$. Participants were excluded if they did complete baseline demographic questions

168 and if they did complete both module 1 and module $2(n=9)$. Students' mean age was $19.4( \pm 1.4)$

169 years old and $73.8 \%$ were female. All descriptive variables were normally distributed. Reported

170 major was grouped into three categories: 1) Arts and Humanities: social sciences, arts, and

171 undecided (47.5\%); 2) STEM: science, technology, engineering, agriculture, and math (22.2\%);

172 and 3) STEM-Health: nutrition, kinesiology, nursing, pre-med (30.3\%) to examine differences.

173 Significant baseline differences between universities were found for all categorical and

174 descriptive variables. Based on these findings, university was controlled for in the analyses using

175 ANCOVA. Baseline comparisons between groups, after controlling for university, are shown in

176 Table 2 . At baseline, the control group initially had a significantly higher pre-CTD score $(\mathrm{p}<.05)$,

177 but after controlling for university, the difference was no longer significant. No other differences

178 between the CTDM-F group and control group were found.

179

180

181

182

183

184

185

186

187

188

189 190 group.

[TABLE 2]

\section{CT-DM Score}

The hierarchical multiple regression revealed that at step 1, university contributed significantly to the regression model, $F(2,428)=19.11, \mathrm{p}<.001$ and accounted for $8.0 \%$ of the variation in CT-DM-score. Introducing the grouping variable (CTDM-F group vs. control group) explained an additional $3.0 \%$ of the variation in CT-DM score and the change in $\mathrm{R}^{2}$ was significant, $F(1,428)=25.45, \mathrm{p}<.001$. The results show that after controlling for university, the grouping variable explained a significant proportion of the variation in CT-DM scores, demonstrating that the CTDM-F group had a significantly higher CT-DM score than the control 
192 presented in Table 3. Results show a greater percentage of the intervention group made a

193 decision and used significantly more evidence-based reasons to support their decision when

194 compared to the control. However, there were no differences between groups in recognizing the 195 other side's point of view.

196 After controlling for university using repeated measures ANCOVA, there were no 197 between group differences in CTD or GE over time. However, there was a significant within198 group change in CTD for both the CTDM-F group from a mean baseline value of $3.52( \pm .6)$ to a 199 post-intervention mean of $3.63( \pm .6), \mathrm{p}<.01$ and the control group from a baseline mean of 3.54 $200( \pm .6)$ to a post-intervention mean of $3.69( \pm .6), \mathrm{p}<.001$. There were no significant within group 201 changes for GE behavior.

202 For the exploratory SEM path analysis, three model versions were hypothesized and 203 tested using EQS software ${ }^{33}$ : direct, predictive, and mediational models. Findings revealed that 204 compared to a direct model with only a single predictor from group to CT-DM score, and a 205 mediational model with CTD and GE behavior as mediators, a third prediction model with paths 206 from three predictors (group, CTD, and GE behavior) fit best.

207 Macro-level fit indices showed that the $\chi^{2}$, df, CFI, and RMSEA were all in a near208 optimal range for the selected prediction model (Table 4). In contrast, fit indices for the direct 209 effect and mediational pathway indicated that these models were not adequately describing the 210 data. Standardized maximum likelihood parameter estimates for the prediction model path 211 coefficients are shown in Figure 1, along with $\mathrm{R}^{2}$ values. The results indicate that group and 212 interest, (i.e., GE behavior) were significant predictors of CT-DM score, but CTD score was not 213 a significant predictor of CT-DM score. 


\section{DISCUSSION}

216

217

218

219

220

221 and supporting that decision with a greater number of evidence-based reasons. These findings

222 were similar to other interventions that were implemented in semester-long courses ${ }^{34}$,

223 highlighting that online modules with an appropriate framework to facilitate learning can be used

224 as supplemental instruction to support higher order thinking skills. This study demonstrated the

225 importance of incorporating an instructional framework to intentionally teach skills associated

226 with CT-DM as well as encourage the significance of skill development for using critical

227 thinking skills during a decision-making scenario.

228

229

230

231

232

233

234

235

236

The success of the online interactive modules in facilitating CT-DM can be attributed to grounding the curriculum within the social constructivism theory, using PBL, and scaffolding the learning to help students move towards independence in their CT-DM skills. The findings in this study are reinforced by Perry et al. ${ }^{35}$, who implemented similar methods using PBL activities throughout a semester-long course in a large introductory class. Their findings showed that students increased their critical thinking skills from the beginning of the semester compared to the end when exposed to competing viewpoints of topics related to sustainability. Developing critical thinking skills is essential because both educators and employers have expressed the need for students to graduate from higher education with strong critical thinking skills. ${ }^{36,37}$ However, 
237 developing these skills require use of curricula that implement evidence-based instructional

238 practices based on research in the science of teaching and learning.

239 Interestingly, while the experimental group made a decision more often and used more

240 evidence to support their decision, the CTDM-F was not successful at having students recognize

241 the differing perspective. One reason for this may be because a discussion activity was not

242 included, which has shown to encourage recognition of other perspectives and to identify the

243 other side's point of view. ${ }^{38}$ Extending the framework by adding an additional module with more

244 scaffolding and a discussion activity would help students move towards greater independence in

245 their CT-DM response.

246 The current study found no significant differences between groups in change in attitudes

247 toward critical thinking measured by CTD; both groups increased scores from baseline to post.

248 The increase in the CTD scores over time can be explained by both groups being exposed to the

249 same components of PBL instruction such as the critical thinking video, the competing narratives

250 in both modules and the decision-making activity. ${ }^{39,40}$ Additionally, there were no changes in

251 GE behavior from pre-test to post-test or between groups. This suggests that even though the

252 modules provided pros and cons of different environmental eating positions, additional

253 intervention components such as goal setting may be needed to lead to behavior change. ${ }^{25}$

254 The path analysis showed that the CTDM-F and GE behavior were significant,

255 independent predictors of CT-DM score, while CTD was not. This provides additional support

256 that the framework encouraged the use of CT-DM skills. The path analysis showed that a

257 prediction model fit better than a mediation or null model. This indicates that interest, or

258 frequency of GE behavior, is an important variable to consider when predicting CT-DM score,

259 but it was not a meditating variable, so it did not strengthen or weaken the CT-DM score. 
Researchers have found that when students express more interest in a topic, they have a

261 greater motivation to engage in critical thinking activities during low stakes assessment (e.g.,

262 extra credit). ${ }^{41,42}$ Bruna et al. ${ }^{21}$ found that when PBL was used to teach metabolism using

263 nutrition and health articles, instead of a traditional lecture format, students reported more

264 motivation to participate, engaged more in self-directed learning, and reported that the learning

265 process encouraged them to use critical thinking skills. The authors contributed the positive

266 outcomes of the study to the use of authentic education material where students were solving

267 real-world problems. This supports why GE behavior was a significant predictor of CT-DM

268 score. While GE may have led to a higher CT-DM score for those reporting higher GE behavior,

269 it may have reduced CT-DM scores for those students who were not as involved in sustainable

270 eating behavior. Nevertheless, the importance of interest in a topic was reinforced by the path

271 analysis findings.

272 The path analysis also revealed that CTD score did not account for a significant amount

273 of variation in CT-DM score. This is conflicting with other studies that have found that CTD is

274 an indicator of critical thinking skills ${ }^{43}$, however the main outcome for this study measured CT-

275 DM skills rather than the larger construct of critical thinking, which is a possible explanation as

276 to why CTD was not a significant predictor of the outcome. Furthermore, having a natural

277 inclination to be a critical thinker does not equate to having strong critical thinking skills. ${ }^{31}$ For

278 example, students may have recognized the need to use critical thinking in their courses (i.e.,

279 measured by CTD score) but may not have progressed to the stage of implementing those

280 strategies (i.e., measured by CT-DM score). Overall, the CT-DM framework intervention was

281 not sufficient to cause a change in students' CTD when compared to the control. 
283 construct of critical thinking, which limits the ability to completely understand how the CTDM-F

284 impacted students' ability to think critically. Despite the limitation, this intervention used a

285 rigorous study design and introduced a novel approach that facilitated CT-DM skills by using an 286 online interactive framework that can be easily administered online or in a classroom setting and 287 be manipulated to fit multiple topics within the STEM fields and beyond.

\section{IMPLICATIONS FOR FUTURE RESEARCH AND PRACTICE}

292 such as social constructivism theory and PBL when developing curricula, along with using topics 293 that students can relate to such as examining sustainable food system practices and making food

294 choices. Through the science of teaching and learning educators have the opportunity to develop 295 curricula that encourages students to consider and evaluate facts, which is imperative for STEM 296 students to master as they begin their careers. As future professionals, this generation faces

297 future problems that are unpredictable and while information is more abundant than ever, the use 298 of the internet and technology requires information seekers to be critical of the facts they 299 consider when making complex decisions.

300 To further enhance the science of teaching and learning, the CTDM-F should be tested 301 and administered in classroom settings to examine how a framework can be used to develop 302 critical thinking skills and help students make informed decisions. Future implications include 303 understanding how the CTDM-F can work to overcome pre-existing biases or emotional 304 reasoning during a decision making scenario, along with measuring the broader construct of 
critical thinking using validated measures. ${ }^{10,44}$ This would provide a more complete

306 understanding of how critical thinking impacts students' decisions. As evident by this study,

307 using a framework within two online interactive modules was found to be a facilitator of CT-DM

308 and students were more likely to recognize and use facts when making a simulated decision

309 about food choices.

1. Butler HA. Halpern Critical Thinking Assessment Predicts Real- World Outcomes of Critical Thinking. Applied Cognitive Psychology. 2012;26(5):721-9.

2. Desai MS, Berger BD, Higgs R. Critical thinking skills for business school graduates as demanded by employers: a strategic perspective and recommendations. Academy of Educational Leadership Journal. 2016;20(1).

3. Dwyer CP, Hogan MJ, Stewart I. An integrated critical thinking framework for the $21 \mathrm{st}$ century. Thinking Skills and Creativity. 2014;12:43-52.

4. Franco A, Costa PS, Almeida LS. Do critical thinkers drink too much alcohol, forget to do class assignments, or cheat on exams? Using a critical thinking measure to predict college students' real-world outcomes. Psychological Studies. 2017:1-10.

5. Knight JK, Wood WB. Teaching more by lecturing less. Cell Biol. Educ. 2005;4(4):298310.

6. Gasiewski JA, Eagan MK, Garcia GA, et al. From gatekeeping to engagement: A multicontextual, mixed method study of student academic engagement in introductory STEM courses. Research in higher education. 2012;53(2):229-61.

7. Duron R, Limbach B, Waugh W. Critical thinking framework for any discipline.

8. Rudd R, Baker M, Hoover T. Undergraduate agriculture student learning styles and critical thinking abilities: Is there a relationship? Journal of agricultural education. 2000;41(3):2-12.

9. Scheffer BK, Rubenfeld MG. A consensus statement on critical thinking in nursing. Journal of Nursing Education. 2000;39(8):352-9.

10. Liu OL, Frankel L, Roohr KC. Assessing Critical Thinking in Higher Education: Current State and Directions for Next- Generation Assessment. ETS Research Report Series. 2014;2014(1):1-23.

11. Brown KL. From teacher-centered to learner-centered curriculum: Improving learning in diverse classrooms. Education. 2003;124(1):49.

12. Huba ME, Freed JE. Learner centered assessment on college campuses: Shifting the focus from teaching to learning. Boston, MA: Allyn and Bacon, 2000.

13. Hendry GD, Frommer M, Walker RA. Constructivism and problem- based learning. Journal of further and higher education. 1999;23(3):369-71. 
14. Mughal F, Zafar A. Experiential learning from a constructivist perspective: Reconceptualizing the Kolbian cycle. International Journal of Learning and

15. Taylor PC. Constructivism: value added. International handbook of science education. 1998;2:1111-23.

16. Vygotsky LS. Thought and Language: MIT Press, Massachusetts Institute of Technology and John Wiley and Sons, 1962.

17. Hannafin MJ, Hill JR, Land SM. Student-centered learning and interactive multimedia: Status, issues, and implication. Contemporary Education. 1997;68(2):94.

18. Yew EH, Karen G. Problem-based learning: an overview of its process and impact on learning. Health Professions Education. 2016;2(2):75-9.

19. Kim K, Sharma P, Land SM, et al. Effects of Active Learning on Enhancing Student Critical Thinking in an Undergraduate General Science Course. Innovative Higher Education. 2013;38(3):223-35.

20. Kek M, Yih Chyn A, Huijser H. The power of problem- based learning in developing critical thinking skills: preparing students for tomorrow's digital futures in today's classrooms. Higher Education Research \& Development. 2011;30(3):329-41.

21. Bruna CE, Valenzuela NA, Bruna DV, et al. Learning Metabolism by Problem- Based Learning Through the Analysis of Health or Nutrition Articles from the Web in Biochemistry. Journal of Food Science Education. 2019;18(2):37-44.

22. Pintrich PR, Smith DAF, García T, et al. Reliability and predictive validity of the Motivated Strategies for Learning Questionnaire (MSLQ). Educational and psychological measurement. 1993;53(3):801-13.

23. Trosset C, Weisler S. Using longitudinal assessment data to improve retention and student experiences. New Directions for Institutional Research. 2010;2010(S2):79-88.

24. Weller KE, Greene GW, Redding CA, et al. Development and validation of green eating behaviors, stage of change, decisional balance, and self-efficacy scales in college students. J Nutr Educ Behav. 2014;46(5):324-33.

25. Monroe JT, Lofgren I, Sartini BL, et al. The Green Eating Project: Web-based intervention to promote environmentally conscious eating behaviors in United States university students. Public Health Nutrition. 2015;18(13):2368-78.

26. Chaillé C. Constructivism across the curriculum in early childhood classrooms: Big ideas as inspiration: Allyn \& Bacon, 2008.

27. Brand-Gruwel S, Wopereis I, Vermetten Y. Information problem solving by experts and novices: Analysis of a complex cognitive skill. Computers in Human Behavior. 2005;21(3):487-508.

28. Wheeler LA, \& Collins, S. K. . The influence of concept mapping on critical thinking in baccalaureate nursing students. J Prof Nurs. 2003;19(6):339-46.

29. Rosen Y, Tager M. Making Student Thinking Visible through a Concept Map in Computer-Based Assessment of Critical Thinking. Journal of Educational Computing Research. 2014;50(2):249-70.

30. Horacek TM, Erdman MB, Byrd-Bredbenner C, et al. Assessment of the dining environment on and near the campuses of fifteen post-secondary institutions. Public Health Nutr. 2013;16(7):1186-96. 
31. Stupnisky RH, Renaud RD, Daniels LM, et al. The interrelation of first-year college students' critical thinking disposition, perceived academic control, and academic achievement. Research in Higher Education. 2008;49(6):513-30.

32. Harlow LL. The essence of multivariate thinking: Basic themes and methods: Routledge, 2014.

33. Bentler PM. EQS Structural Equations Program Manual. Encino, CA: Multivaritate Software Inc., 2006.

34. Şendağ S, Ferhan Odabaşı H. Effects of an online problem based learning course on content knowledge acquisition and critical thinking skills. 2009:132-41.

35. Perry DK, Burgess MH, Sowell BF, et al. Using Competing Narratives to Increase Critical Thinking Abilities. NACTA Journal. 2017;61(1):41.

36. Accreditation Council for Education in Nutrition and Dietetics, Commission on Dietetic Registration, Council on Future Practice, Education Committee, Nutrition \& Dietetics Educators and Preceptors DPG. 2013.

37. Easterly T, Warner AJ, Myers BE, et al. Skills Students Need in the Real World: Competencies Desired by Agricultural and Natural Resources Industry Leaders. Journal of Agricultural Education. 2017;58(4):225-39.

38. Guiller J, Durndell A, Ross A. Peer interaction and critical thinking: Face-to-face or online discussion? Learning and instruction. 2008;18(2):187-200.

39. Abrami PC, Bernard RM, Borokhovski E, et al. Instructional interventions affecting critical thinking skills and dispositions: A stage 1 meta-analysis. Review of Educational Research. 2008;78(4):1102-34.

40. Dochy F, Segers M, Van den Bossche P, et al. Effects of problem-based learning: A meta-analysis. Learning and instruction. 2003;13(5):533-68.

41. Liu OL, Bridgeman B, Adler RM. Measuring learning outcomes in higher education: Motivation matters. Educational Researcher. 2012;41(9):352-62.

42. Weiler A. Information-seeking behavior in generation y students: Motivation, critical thinking, and learning theory. J Acad Libr 2005;31(46):53.

43. Profetto-McGrath J. The relationship of critical thinking skills and critical thinking dispositions of baccalaureate nursing students. J. Adv. Nurs. 2003;43(6):569-77.

44. Abrami PC, Bernard RM, Borokhovski E, et al. Strategies for teaching students to think critically: A meta-analysis. Review of Educational Research. 2015;85(2):275-314. 
Table 1: Differences in Module 1 and 2 Design Between Critical Thinking Decision Making Framework (CTDM-F) Group and Control Group

\section{CTDM-F Group Control Group}

Module 1:

Animal/Plant Protein

\begin{tabular}{rcc} 
Topic & $\begin{array}{c}\text { Introduced in the form } \\
\text { of a problem }\end{array}$ & $\begin{array}{c}\text { Introduced as } \\
\text { the topic }\end{array}$ \\
\hline Support & $\begin{array}{c}\text { T-Chart } \\
\text { Mind-Map } \\
\text { Structured fill in } \\
\text { the blanks }\end{array}$ & None \\
\hline $\begin{array}{r}\text { Module 2: } \\
\text { Organic/Non-Organic }\end{array}$ & Text box \\
\hline Topic & $\begin{array}{c}\text { Introduced in the form } \\
\text { of a problem } \\
\text { T-Chart } \\
\text { Mind-Map }\end{array}$ & Introduced as the topic \\
\hline Support & Text box & None \\
\hline Decision-Making Activity & Text box
\end{tabular}




\begin{tabular}{|c|c|c|c|}
\hline Variable & $\begin{array}{c}\text { CTDM-F (n=203) } \\
\text { mean (std) }\end{array}$ & $\begin{array}{c}\text { Control }(n=228) \\
\text { mean (std) }\end{array}$ & F-Value \\
\hline Age & $19.3(1.3)$ & $19.4(1.5)$ & 1.82 \\
\hline Pre-CTD ${ }^{a}$ & $3.51(.6)$ & $3.54(.6)$ & .50 \\
\hline Pre-GE Behavior $^{\mathrm{b}}$ & $2.72(.7)$ & $2.76(.8)$ & .29 \\
\hline Variable & $\begin{array}{c}\text { CTDM-F }(n=203) \\
\%\end{array}$ & $\begin{array}{c}\text { Control }(\mathrm{n}=\mathbf{2 2 8}) \\
\%\end{array}$ & $\begin{array}{c}\text { Pearson } \\
\text { Chi-Square } \\
\end{array}$ \\
\hline Gender & $\begin{array}{l}26.6 \\
73.4 \\
\end{array}$ & $\begin{array}{l}26.0 \\
74.0\end{array}$ & .03 \\
\hline $\begin{array}{r}\text { Major }^{\mathbf{c}} \\
\text { Arts and Humanities } \\
\text { STEM } \\
\text { STEM-Health } \\
\text { Undecided }\end{array}$ & $\begin{array}{c}42.4 \\
23.6 \\
28.6 \\
5.4\end{array}$ & $\begin{array}{c}42.4 \\
20.5 \\
31.4 \\
5.7\end{array}$ & .85 \\
\hline $\begin{array}{ll}\text { University }^{\mathrm{d}} & \\
& \text { University } 1 \\
& \text { University } 2 \\
\end{array}$ & $\begin{array}{l}50.7 \\
49.3 \\
\end{array}$ & $\begin{array}{l}55.7 \\
44.3 \\
\end{array}$ & 1.06 \\
\hline \multicolumn{4}{|c|}{$\begin{array}{l}{ }^{\mathrm{a}} \mathrm{CTD}=\text { Critical Thinking Disposition, Motivated Strategies for Learning Questionnaire (MSLQ), mean score of } \\
\text { five items measured using a 5-point Likert scale: (1) strongly disagree (5) strongly agree. } \\
\text { bPre-GE Behavior= Pre-Green Eating Behavior, 7-item survey, 5-point Likert scale ranging from (1) barely ever } \\
\text { to never to (5) almost always. } \\
{ }^{c} \text { Arts and Humanities= social sciences, arts, and undecided; STEM Majors= Science, Technology, Engineering, } \\
\text { and Math; STEM-Health Majors= nutrition, kinesiology, nursing, pre-med } \\
{ }^{d} \text { University 1= University of Rhode Island; University 2= University of North Texas } \\
\text { Continuous variables assessed using ANCOVA, controlling for university } \\
\text { Categorical variables assessed using Pearson Chi-Square }\end{array}$} \\
\hline
\end{tabular}




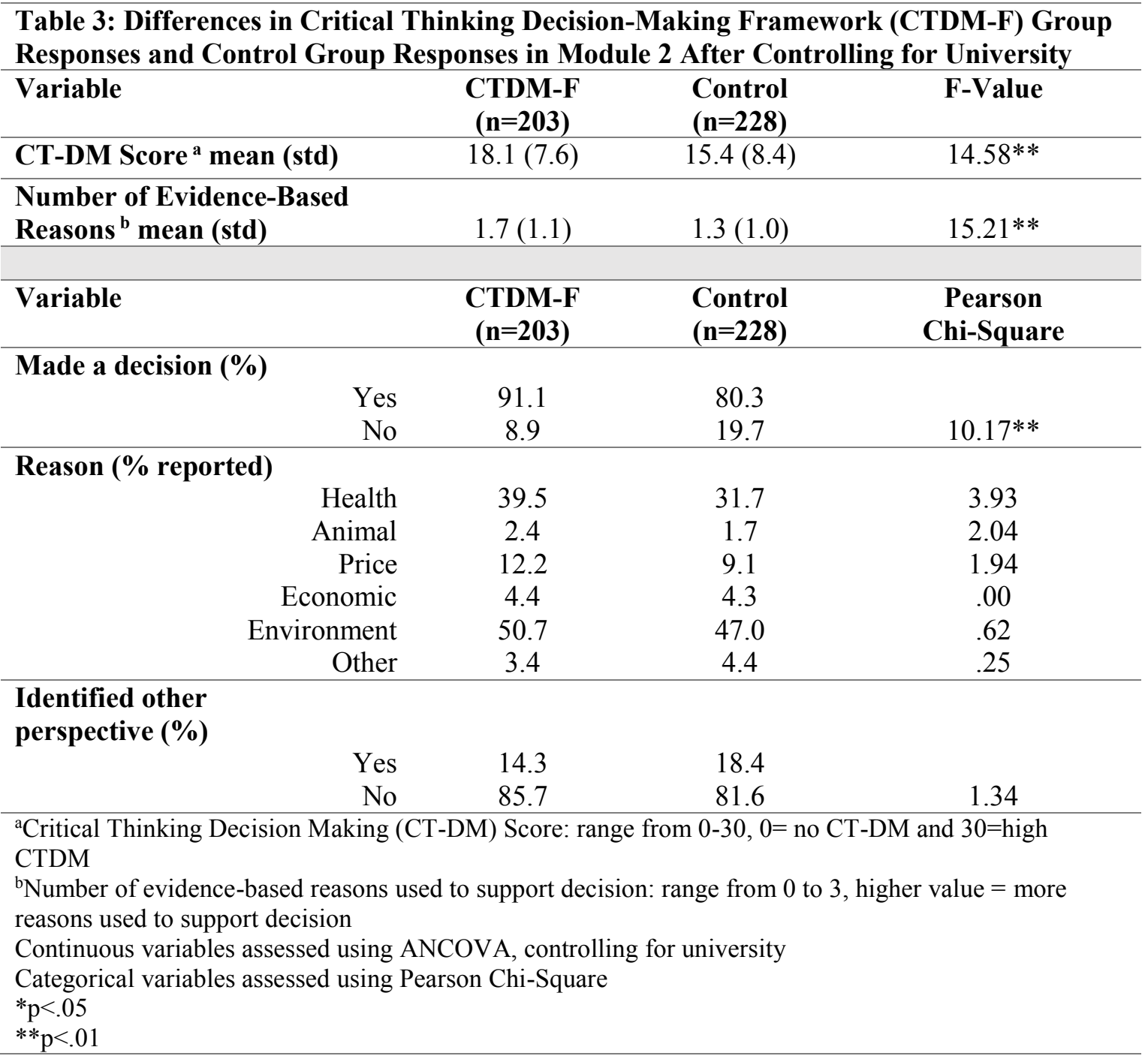




\begin{tabular}{|c|c|c|c|c|c|c|}
\hline \multirow[t]{2}{*}{ Pathway } & \multicolumn{6}{|c|}{ Macro-Level Fit Indices ${ }^{d}$} \\
\hline & $\mathbf{X}^{2}$ & df & $\mathrm{X}^{2} / \mathrm{df}$ ratio & CFI & RMSEA & $X^{2}$ difference \\
\hline Direct $^{\mathrm{a}}$ & $21.82 *$ & 5 & 4.36 & .302 & .093 & --- \\
\hline Mediational $^{b}$ & $21.72 *$ & 2 & 10.86 & .181 & .159 & .10 \\
\hline Predictive $^{c}$ & $14.65^{*}$ & 3 & 4.88 & .516 & .100 & 7.07 \\
\hline $\begin{array}{l}\text { a'Direct pathway } \\
{ }^{\mathrm{b}} \text { Mediational pa } \\
\text { CT-DM score } \\
\text { cPredictive path } \\
\text { score } \\
{ }^{\mathrm{d}} \text { Ideal macro-le } \\
\text { value equates to } \\
{ }^{\mathrm{c} p}<.001\end{array}$ & $\begin{array}{l}\mathrm{m} \text { group } \mathrm{t} \\
\text { ay with gr } \\
\text { with grot } \\
\text { it indices } \\
\text { er fit }\end{array}$ & $\begin{array}{l}\text { al th } \\
\text { inde } \\
\text { n ea }\end{array}$ & $\begin{array}{l}\text { ecision making } \\
\text { variable and } \mathrm{G} \\
\text { behavior, and } \\
.05, \mathrm{X}^{2} / \mathrm{df} \text { ratic }\end{array}$ & $\begin{array}{l}\text { score } \\
\text { and CT } \\
\text { nking c } \\
0.90,\end{array}$ & $\begin{array}{l}\text { iodiating var } \\
\text { iCTD) pr } \\
<<0.08, \mathrm{X}^{2}\end{array}$ & $\begin{array}{l}\text { les explaining } \\
\text { licting CT-DM } \\
\text { ference= larger }\end{array}$ \\
\hline
\end{tabular}


Figure 1: Prediction Model Pathway with Parameter Estimates for Critical Thinking Disposition Score, Group, and Green-Eating Behavior

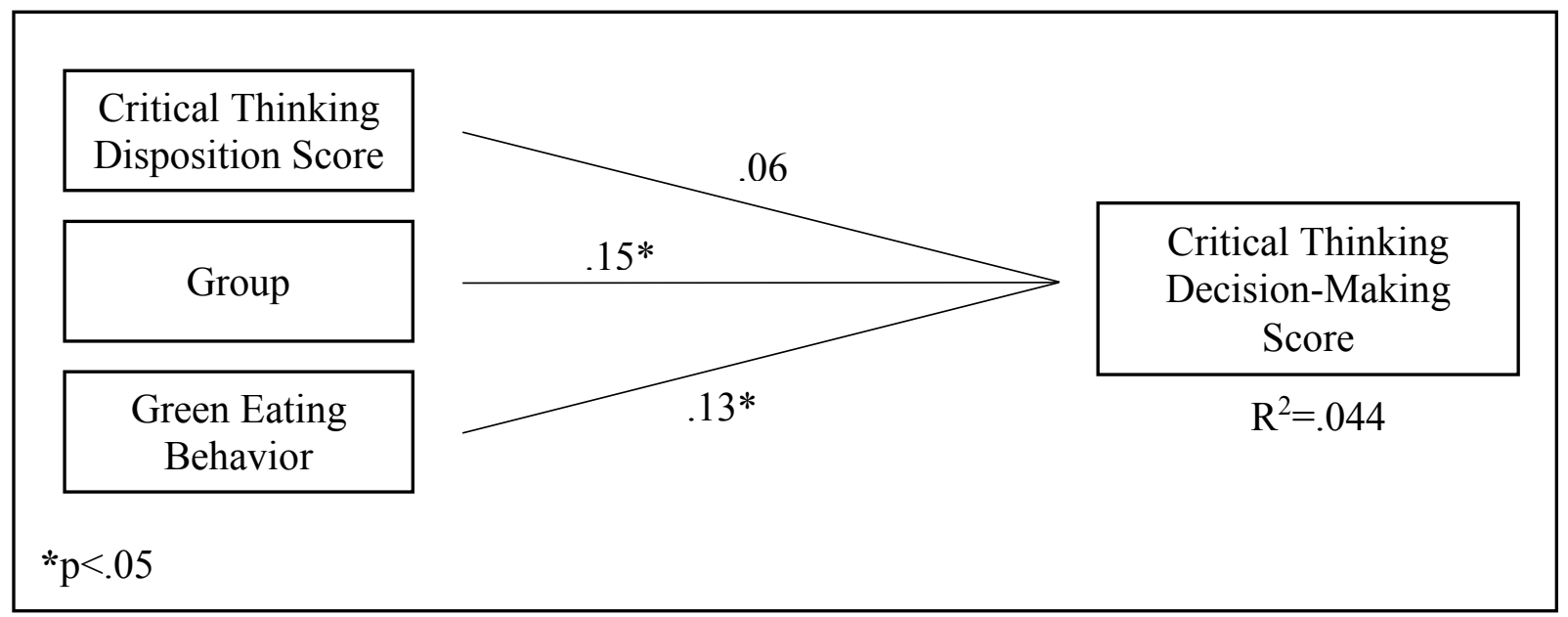

